\title{
IMPLEMENTASI METODE DISKUSI KELOMPOK DALAM UPAYA MENINGKATKAN HASIL BELAJAR SISWA PADA MATA PELAJARAN ILMU PENGETAHUAN SOSIAL
}

\author{
Yhadi Firdiansyah ${ }^{1}$, Nunung Nurlaili ${ }^{2}$ \\ 1,2Universitas Islam Negeri Maulana Malik Ibrahim Malang \\ Email:Yhadi_firdiansyah@uin-malang.ac.id
}

\begin{abstract}
Abstrak : Tujuan penelitian ini adalah untuk memberikan solusi metode dalam pembelajaran serta untuk meningkatkan hasil belajar siswa kelas VIII B pada mata pelajaran IPS di MTs Hasyim Asyari Kota batu yang diperoleh ketika guru mengimplementasikan metode diskusi. Metode yang digunakan peneliti adalah penelitian tindakan kelas, yang mana penelitian terdiri dari 2 siklus, dan empat tahapan diantaranya perencanaan, pelaksanaan, pengamatan, dan refleksi. Pada siklus pertama banyak siswa yang mendapat nilaidi bawah dari nilai ketuntasan atau KKM dimana sebanyak $60 \%$ siswa yang belum memenuhi nilai kriteria minimal. Sedangkan siswa yang memenuhi nilai ketuntasan yaitu hanya $40 \%$.Pada siklus ke dua hasil belajar diperoleh sebanyak $86,67 \%$ siswa mampun memperoleh nilai $\geq 70$ dan dinyatakan tuntas, sedangkan $13,33 \%$ siswa yang memperoleh nilai $<70$ yang artinya terdapat 2 siswa yang masih belum tuntas.
\end{abstract}

Kata kunci : Metode diskusi, Hasil Belajar

\section{PENDAHULUAN}

Pendidikan memiliki peranan yang sangat penting karena pendidikan merupakan sarana untuk mengubah persepsi, sikap, dan perilaku manusia (Priyatno, 2013). Pendidikan juga merupakan upaya strategis untuk mengangkat harkat dan martabat bangsa melalui tersedianya sumberdaya manusia yang berkualitas. Salah satu tujuan dari bangsa Indonesia yang tertuang dalam pembukaan UUD 1945 dimana salah satu upaya yang dilakukan pemerintah misalnya dengan memperbaiki kualitas pendidikan dengan cara meningkatkan kualitas guru, karena kualitas pendidikan suatu negara ditentukan oleh kualitas pendidiknya, sehingga dengan kualitas pendidikan yang baik maka akan menghasilkan sumber daya manusia yang baik dan berkualitas pula (fieka, 2019).

Kualitas guru yang baik tercermin dari bagaimana kegiatan belajar yang dilakukannya bersama dengan peserta didik, karena kegiatan belajar merupakan kegiatan yang paling pokok, yang artinya yaitu berhasil tidaknya pencapian tujuan pendidikan banyak bergantung pada bagaimana proses belajar yang dialami peserta didik (Slameto, 2003). Proses belajar mengajar 
tidak terlepas dari komponen-komponen pendidikan diantaranya tujuan pendidikan, peserta didik, isi pendidikan, pendidik, lingkungan pendidikan, alat pendidikan dan metode pendidikan. Hal lain juga diungkapkan oleh dwi Siswoyo, dkk. Di dalam komponen pendidikan ada tiga unsur sentral dalam upaya pendidikan. Tiga unsur sentral tersebut adalah pendidik atau guru, peserta didik atau siswa dan tujuan pendidikan. Proses pendidikan akan terjadi bila ketiga unsur tersebut saling berhubungan secara fungsional dalam satu kesatuan yang padu. Oleh karena itu, guru sebagai salah satu unsur sentral dalam pendidikan memiliki peranan penting dalam proses pembelajaran untuk mengantarkan siswa kepada tujuan pendidikan yang telah ditetapkan (Siswoyo, 2007).

Di dalam komponen pendidikan yakni metode tentunya terdapat beberapa metode yang dilakukan oleh guru dalam mendidik yaitu diantaranya metode ceramah, metode ini merupakan metode pengajaran dengan cara yang konvensional yaitu dengan meyampaikan infromasi secara lisan kepada peserta didik. Metode ini dianggap sebagai metode yang praktis dan ekonomis. Namun metode ini memiliki kelemahan untuk dilakukan pada saat ini, karena dengan pendekatan metode ceramah manjadikan siswa kurang aktif sehingga pembelajaran tidak menjadi efektif. (Hamalik, 2001) mengemukakan bahwa pengajaran yang efektif adalah pengajaran yang menyediakan kesempatan belajar sendiri atau melibatkan aktivitas sendiri, artinya pembelajaran yang efektif memerlukan keterlibatan siswa di dalamnya. Siswa ditempatkan sebagai subjek didik, sebagai subjek didik siswa harus terlibat aktif dalam proses pembelajaran. Siswa tidak hanya bertugas menerima segala macam informasi tetapi siswa harus berusaha mendapatkan dan memperoleh informasinya dengan usahanya sendiri.

Guna tercapai pembelajaran yang baik dan efektif guru sangat memiliki peran besar dimana guru berperan dalam setiap keberhasilan yang dicapai setiap proses pembelajaran yang terjadi di sekolah. Guru juga memiliki kewajiban dan tanggung jawab untuk mengatur, mengarahkan, menciptakan suasana yang nyaman dan kondusif didalam proses pembelajaran(Sanjaya, 2006).Guru harus bisa menguasai berbagai macam metode pengajaran yang ada sesuai dengan perkembangan zaman utamanya di zaman milenial. Metode juga dapat diartikan sebagai prosedur kegiatan yang dipilih sebagaialat atau fasilitas untuk membantu siswa mencapai tujuan yang sesuai dengan proses pembelajaran yang diharapkan(Wena, 2009).

Berdasarkan hasil pengamatan peneliti selama melakukan kegiatan pembelajaran, ada beberapa masalah yang ditemui dalam pembelajaran tersebut.Diantaranya, 1) guru melakukan kegiatan pembelajaran dengan metode ceramah. 2) guru hanya sebagai pemberi informasi kepada peserta didik. 3)peserta didik di MTs Hasyim Asy'ari khususnya kelas VIII B masih 


\section{IMPLEMENTASI METODE DISKUSI KELOMPOK DALAM UPAYA MENINGKATKAN HASIL BELAJAR SISWA PADA MATA PELAJARAN ILMU PENGETAHUAN SOSIAL}

belum sepenuhnya memerhatikan penjelasan guru, sehingga peserta didik kurang dapat memahami materi yang telah disampaikan oleh guru. Beberapa peserta didik dapat mengikuti kegiatan pembelajaran dengan baik.Namun ada beberapa peserta didik yang masih belum bisa memahami maksud materi yang disampaikan oleh guru.Beberapa peserta didik dapat memahami penjelasan dari guru berupa pengertian suatu istilah.Namun masih belum memahami ketika peserta didik diminta untuk menganalisis suatu permasalahan.

Berdasarkan permasalahan tersebut, maka peneliti berencana untuk memberi solusi pembelajaran berupa kegiatan diskusi kelompok. Metode diskusi kelompok menurut (Hasibuan, 2006) mengatakan bahwa diskusi merupakan proses penglihatan dua atau lebih individu yang berinteraksi secara verbal dan saling berhadapan muka mengenai tujuan atau sasaran yang sudah tertentu melalui cara menukar informasi, mempertahankan pendapat atau pemecahan masalah.Pemilihan metode tersebut adalah agar peserta didik dapat melakukan diskusi dengan teman sebayanya.Peserta didik dapat saling bertukar hasil pemikiran masingmasing dengan peserta didik lainnya. Peserta didik yang sudah dapat memahami penjelasan dari guru, dapat menyalurkan pemahamannya dengan peserta didik lain dalam kelompok tersebut. sehingga penjelasan tidak hanya didapatkan dari guru saja, tetapi juga dapat disampaikan oleh peserta didik lain. Serta diharapkan seluruh peserta didik mendapat pemahaman yang sama.

\section{METODE}

Penelitian ini menggunakan penelitian tindakan kelas yang dilakukan untuk meningkatkan hasil belajar siswa pada mata pelajaran IPS, serta digunakan dalam rangka untuk memberikan solusi dalam pembelajarannya. menurut (Arikunto \& Supardi, 2006) penelitian tindakan kelas merupakan suatu pencermatan terhadap kegiatan belajar berupa sebuah tindakan, yang sengaja dimunculkan dan terjadi dalam sebuah kelas secara bersama. Penelitian tindakan kelas ini dapat dilakukan dengan menggunakan metode pembelajaran diskusipada mata pelajaran IPS. Penelitian ini dilakukan di MTs Hasyim Asyari Kota Batu dengan subjek penelitian siswa kelas VIII B tahun ajaran 2019/2020 dengan jumlah siswa sebanyak 15 siswa.

Teknik pengumpulan data dilakukan dengan observasi, dokumentasi dan metode tes, adapun observasi yang dilakukan adalah sebelumpenelitian dan saat berlangsungnya penelitian. Observasi sebelum penelitian untukmengetahuipermasalahan yangterjadidi Kelas VIIIB, yang kemudian observasi juga dilaksanakan pada saat penelitian berlangsung yang berguna untuk menganalisis penelitian. Kemudian peneliti menggunakan metode tes tulis dengan melakukan testulis kepada beberapa siswa kelas VIIIB untuk 
memperoleh atau mengukur daya serap siswa. Dan yang terakhir yakni dengan teknik dokumentasi, teknik dokumentasi dilakukan dengan cara memberi tugas kepada siswa yang hasilnya akan dianalisis untuk dijadikan hasil penelitian.

Teknik analisis data dilakukan dengan indikator keberhasilan penelitian tindakan kelas ini adalah diharapkan dari implementasi metode diskusi dapat meningkatkan hasil belajar dengan memperoleh nilaiketuntasan 70 pada minimal $80 \%$ darisiswa yang terlibat aktif dalam pembelajaran. Teknik analisis data adalah melalui data yang diperoleh dari hasil tanya-jawab, catatan lapangan, dan bahan-bahan lain, sehingga dapat mudah dipahami, dan temuannya diinformasikan kepada orang lain. Analisis yang bisa dipakai yaitu analisis kuantitatif dan kualitatif(Prastowo, 2011).

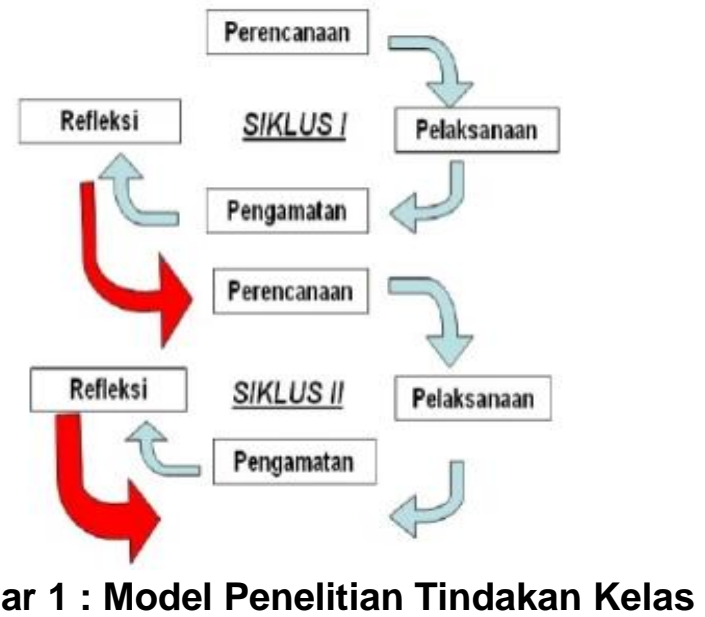

\section{HASIL DAN PEMBAHASAN}

\section{Hasil}

Penelitian ini dilakukan pada siswa kelas VIII B MTs Hasyim Asyari Kota tahun pelajaran 2019/2020. Penelitian tindakan kelas ini dilakukan dalam dua siklus dengan melalui 4 tahapan yaitu perencanaan, pelaksanaan, pengamatan dan refleksi.Pada tahap pertemuan pertama,guru memberikan materi dengan metode ceramah. Dalam kegiatan ini,guru menjelaskan dengan cara memberi contoh kepada siswa.Kemudian siswa diberi pertanyaan terkait materiyang telah disampaikanoleh guru.Namun siswa masih kesulitan memahami materi yang telah disampaikan oleh guru.Terlihat pada saat guru memberikan tes tulis kepada siswa masih banyak siswa yang mendapat nilaidi bawah dari nilai ketuntasan atau KKM dimana sebanyak $60 \%$ siswa yang belum memenuhinilai kriteria minimal. Sedangkan siswa 


\section{IMPLEMENTASI METODE DISKUSI KELOMPOK DALAM UPAYA MENINGKATKAN HASIL BELAJAR SISWA PADA MATA PELAJARAN ILMU PENGETAHUAN SOSIAL}

yang memenuhi nilai ketuntasan yaitu hanya $40 \%$. Hal ini menunjukan bahwa sebagian besar siswa masih belum sepenuhnya memahami materi yang disampaikan.

Untuk menganalisis ketuntasan belajar siswa dapat digunakan dengan rumus :

$$
\begin{array}{rl}
N P=\frac{R}{S N} X 100 \% & \mathrm{NP}=\text { Nilai Persetase } \\
& \mathrm{R}=\text { jumlah siswa yang memperoleh nilai }<70 \\
& \mathrm{SN}=\text { jumlah keseluruhan siswa }
\end{array}
$$

Siklus 1 nilai persentase siswa yang tidak tuntas

$$
\begin{aligned}
& N P=\frac{9}{15} X 100 \% \\
& N P=60 \%
\end{aligned}
$$

Tabel 1. HasilBelajar IPS siswa kelas VIII Siklus 1

\begin{tabular}{|l|l|c|c|l|}
\hline No & \multicolumn{1}{|c|}{ Nama } & Nilai & KKM & Keterangan \\
\hline 1 & Achmad RaflyKhoironi & 53 & 70 & Tidak tuntas \\
\hline 2 & Armanda GalangSaputra & 58 & 70 & Tidak tuntas \\
\hline 3 & Ayuning Qodariyah & 68 & 70 & Tidak tuntas \\
\hline 4 & Dimas Prayoga & 65 & 70 & Tidak tuntas \\
\hline 5 & Enrizal Febrian Iswiyanto & 70 & 70 & Tuntas \\
\hline 6 & Fernando Ariyo Moreyno & 75 & 70 & Tuntas \\
\hline 7 & Mochammad Zidan ArdiSaputra & 70 & 70 & Tuntas \\
\hline 8 & MuhammadAbiyyuDhiya Ulhaq & 80 & 70 & Tuntas \\
\hline 9 & Ilmia Inka & 60 & 70 & Tidak tuntas \\
\hline 10 & Nazwa Natamia Soliha & 75 & 70 & Tuntas \\
\hline 11 & Nellyn Citra Winandha & 65 & 70 & Tidak tuntas \\
\hline 12 & Novitalsnaeni NurHidayah & 65 & 70 & Tidak tuntas \\
\hline 13 & Ony Audia Nesha & 70 & 70 & Tuntas \\
\hline 14 & Siti SyarahNur Ramadani & 60 & 70 & Tidak tuntas \\
\hline 15 & Riska FitriAriyanti & 53 & 70 & Tidak tuntas \\
\hline
\end{tabular}

Pada kegiatan pembelajaran berikutnya, guru menggunakan metode yang berbeda yaitu metode diskusi, pada tahap pertama guru memberikan penjelasan dalam bentuk metode ceramah kepada siswa yang kemudian 
dilanjutkan dengan membagi siswa kedalam beberapa kelompok. Dalam aktivitas ini siswa sudah cukup baik, karena siswa mampu berperanaktifdalam proses pembelajaran dimana siswasudah tidakragulagi dalam bertanya tentang apa yang belum dipahami. Selain itu antar siswa bisa saling bertukar pendapat antar anggota kelompok. Setelah melakukan kegiatan diskusi siswa juga diminta untuk menyampaikan hasil diskusinya di depan kelas. kegiatan ini menuntut siswa untuk lebih aktif lagi dan berani menyampaikan pendapatnya. Sebagai tolak ukur sejauh mana siswa memahami materi tersebut,maka guru melakukan tes tulis dimana hasil yang diperoleh sebagai berikut ini :

Tabel 2. Hasil Belajar IPS siswa kelas VIII Siklus 2

\begin{tabular}{|l|l|c|c|l|}
\hline No & \multicolumn{1}{|c|}{ Nama } & Nilai & KKM & Keterangan \\
\hline 1 & Achmad RaflyKhoironi & 73 & 70 & Tuntas \\
\hline 2 & Armanda Galang Saputra & 66 & 70 & TidakTuntas \\
\hline 3 & Ayuning Qodariyah & 80 & 70 & Tuntas \\
\hline 4 & Dimas Prayoga & 78 & 70 & Tuntas \\
\hline 5 & Enrizal Febrian Iswiyanto & 88 & 70 & Tuntas \\
\hline 6 & Fernando Ariyo Moreyno & 90 & 70 & Tuntas \\
\hline 7 & Mochammad Zidan ArdiSaputra & 80 & 70 & Tuntas \\
\hline 8 & MuhammadAbiyyuDhiya Ulhaq & 88 & 70 & Tuntas \\
\hline 9 & Ilmia Inka & 78 & 70 & Tuntas \\
\hline 10 & Nazwa Natamia Soliha & 85 & 70 & Tuntas \\
\hline 11 & Nellyn Citra Winandha & 87 & 70 & Tuntas \\
\hline 12 & NovitalsnaeniNurHidayah & 83 & 70 & Tuntas \\
\hline 13 & Ony Audia Nesha & 85 & 70 & Tuntas \\
\hline 14 & Siti SyarahNur Ramadani & 86 & 70 & Tuntas \\
\hline 15 & Riska FitriAriyanti & 68 & 70 & Tidak tuntas \\
\hline
\end{tabular}

Dari data hasil belajar pada siklus kedua diperoleh sebanyak 86,67 \% siswa mampun memperoleh nilai $\geq 70$ dan dinyatakan tuntas, sedangkan $13,33 \%$ siswa yang memperoleh nilai $<70$ yang artinya terdapat 2 siswa yang masih belum tuntas, beikut ini cara analisisnya pada siklus ke 2 :

Siklus 2 nilai persentase siswa yang tuntas

$$
\begin{aligned}
& N P=\frac{13}{15} X 100 \% \\
& N P=86,67 \%
\end{aligned}
$$




\section{IMPLEMENTASI METODE DISKUSI KELOMPOK DALAM UPAYA MENINGKATKAN HASIL BELAJAR SISWA PADA MATA PELAJARAN ILMU PENGETAHUAN SOSIAL}

Berdasar analisis tersebut pada siklus ke 2 menggunakan metode diskusi kelompok, menunjukkan bahwa siswa lebih dapat memahami materi dari dengan metode diskusi kelompok dari pada jika siswa jika hanya memperoleh penjelasan guru dengan metode ceramah.

\section{Pembahasan}

Penelitian ini dilakukan di MTs Hasyim Asyari Kota Batu dengan subjek penelitian siswa kelas VIII B tahun ajaran 2019/2020 dengan jumlah siswa sebanyak 15 siswa. Hasil penelitian ini menunjukkan bahwa dengan metode diskusi siswaakan ikutberperanaktifdalam kegiatan pembelajaran.Darihasilpenelitianpadasikluskedua,siswa yangdapatmencapai nilaiketuntasansebesar $86,87 \%$ yang artinya hasilbelajardan pemahamansiswa terhadapmateri yang dipelajari meningkat. Metode diskusi dengan cara penyajian informasi dalam PBM dimana peserta dihadapkan pada suatu masalah yang berupa pertanyaan atau pernyataan yang bersifat problematic untuk dibahas dan dipecahkan bersama (Daryanto, 2009).

Hal ini disebabkan oleh metode yang dilakukan oleh gurumenuntut siswa agarberperan aktif dalam pembelajaran.Siswaterjunlangsungdalam kegiatandiskusi. Sehingga siswadapat bertukar pikirandengan anggota kelompok mengenai permasalahanyang diberikan oleh guru. Siswajuga diminta untukmenyampaikanhasildiskusinyadidepan kelasdengantujuan agar seluruhsiswadapatsalingmengetahui informasidanpendapatdari temannya dan saling bertukar pikiran. Hasil tersebut diperkuat menurut (Alamsyah said, 2015) bahwa metode diskusi merupakan metode yang menekankan aktivitas belajar melalui interaksi komunikasi antar siswa dan siswa yang lain dalam membahas suatu tema atau tpic sehingga diperoleh kesimpulan.

Sedangkan pada siklus satu guru hanya menggunakan metode ceramah,mencontohkan, serta tanya jawab dengan siswa. Aktifitas penelitian pada siklus satu menunjukan bahwa melakukan kegiatan pembelajaran dengan metode ceramah tersebut masih belum cukup untuk membuat siswa memahami dengan baik apa yang siswa pelajari.Terbukti dengan adanya tes tulis pada siklus satu yang dilakukan diakhir kegiatan pembelajaran, masih banyak siswa yang belum mencapai nilai ketuntasan. Dari hasil penelitian siklus satu,menunjukan guru belum berhasil dalam melakukan kegiatan pembelajaran. Ketika guru menjelaskan,tidak semua siswa mendengarkan dengan seksama. Siswa cenderung merasa bosan dengan apa yang dilakukan oleh guru.Sebagian siswa ramai sendiri karena merasa bosan dengan metode tersebut sehingga siswa yang lain terganggu dengan temannya dan tidak dapat fokus serta berkonsentrasi penuh pada guru. Dari hasil akhir penelitian pada siklus satu,hanya $40 \%$ siswa yang telah mencapai 
nilai ketuntasan. Sedangkan $60 \%$ yang lain masih belumdapatmencapai nilai ketuntasan.

\section{SIMPULAN}

Berdasarkan analisis data dan pembahasan hasil penelitian di atas dapat disimpulkan sebagai berikut :

1. Metode ceramah belum dapat meningkatkan hasil belajar siswa, hal tersebut karena dengan metode ceramah anak cenderung bosan dan kurang terfokus dalam penjelasan gurunya.

2. Metode diskusi dapat menunjukkan keaktifan dan hasil belajar siswa menjadi lebih meningkat. Penerepan metode diskusi ini merupakan langkah-langkah kegiatan pembelajaran yang cukup efektif. Hal tersebut dikarenakan adanya keterlibatan secara langsung kepada siswa dalam proses pembelajaran sehingga suasana dalam pembelajaran semakin menarik dan tentunya siswa bersemangat untuk mengikutinya.

3. Metode diskusi dapat meningkatkan minat dan kemampuan serta mampu untuk menumbuhkkan sikap kerjasama dan keberanian siswa, karena respon-respon tersebut diungkapkan melalui kegiatan diskusi.

\section{REFERENSI}

Alamsyah said, A. B. (2015). Strategi mengajar multiple intelligences.kencana prenadamedia group.

Arikunto, S., \& Supardi.(2006). Penelitian Tindakan Kelas. Bumi Aksara.

Daryanto. (2009). Panduan proses pembelajaran kreatif dan inovatif. AV Publisher.

fieka, U. (2019). Peningkatan kualitas pendidikan: Program profesi guru prajabatan dalam pemenuhan kebutuhan guru profesional di indonesia. 10. https://doi.org/10.22212/aspirasi.v7il.1084

Hamalik, O. (2001). Proses belajar mengajar. PT Bumi Aksara.

Hasibuan.(2006). Proses belajar mengajar.

Prastowo, A. (2011). Metode penelitian kualitatif dalam perspektif rancangan penelitian.Ar-ruzz media. 
IMPLEMENTASI METODE DISKUSI KELOMPOK DALAM UPAYA MENINGKATKAN HASIL BELAJAR SISWA PADA MATA PELAJARAN ILMU PENGETAHUAN SOSIAL

Priyatno, Y. (2013). Pendidikan berperspektif lingkungan menuju pembangunan berkelanjutan.16(1).

Sanjaya. (2006). Strategi pembelajaran berorientasi standart proses pendidikan. kencana.

Siswoyo, D. (2007). IImu Pendidikan. UNY Press.

Slameto.(2003). Belajar dan faktor-faktor yang mempengaruhinya.PT Rineka Cipta.

Wena, M. (2009). Strategi Pembelajaran Inovatif Kontemporer Suatu Tinjauan Konseptual Operasional. Jakarta: Bumi Aksara. 